\title{
Restriction endonucleases in clinical isolates of Shigella spp.
}

\author{
K:-F. LEE, JULIA M.-L. LING*, K.-M. KAM†, D. R. CLARK $\ddagger$ and P.-C. SHAW \\ Departments of Biochemistry and * Microbiology, Chinese University of Hong Kong, †Institute of Pathology, \\ Sai Ying Pun Jockey Club Clinic, Hong Kong and $\ddagger$ GeneSys Ltd, St Albans House, 40 Lynchford Road, \\ Farnborough, Hants GU14 6EF
}

\begin{abstract}
Thirteen restriction endonuclease-containing strains were isolated from a collection of 186 clinical isolates of Shigella spp. Among these, eight and five isolates carried isoschizomers of EcoRII and $\mathrm{NciI}$, respectively. The former restriction-modification (RM) system was homologous to that of EcoRII and was located on plasmids with sizes of 46.6 or $55.6 \mathrm{~kb}$. Isolates producing $\mathrm{Nci}$ il isoschizomers contained a $5.7-\mathrm{kb}$ nontransferable plasmid. Together with antimicrobial susceptibility tests and plasmid profile studies, it is concluded that these two $R-M$ systems are not widely spread but confined to strains with similar antibiotic resistance and plasmid profile.
\end{abstract}

\section{Introduction}

Restriction-modification (R-M) systems exist in many bacterial species [1]. Restriction endonucleases serve to degrade foreign invading DNA and methyltransferases protect the host DNA from its own restriction endonuclease [2]. Some R-M systems are coded for on naturally occurring plasmids and they may contribute to the maintenance of plasmid stability [3-5]. In Hong Kong, infection with Shigella spp. is endemic and constitutes c. $33 \%$ of the notified cases of diarrhoea [6]. Many strains of these species are resistant to multiple antibiotics and carry plasmids [7, 8]. To explore the diversity of restriction endonucleases in Shigella spp. and find if restriction endonuclease production is a useful character for epidemiological studies, this study correlated the occurrence of restriction endonucleases with serotype, antibiotic resistance and plasmid profile, in a local collection of clinical isolates of Shigella spp.

\section{Materials and methods}

\section{Shigella strains}

A total of 186 single isolates of Shigella spp. comprising 124 strains of $S$. flexneri, 61 of $S$. sonnei and one of $S$. boydii, collected from two local hospitals between 1985 and 1994, was examined.

Received 6 Jan. 1997; accepted 28 March 1997.

Corresponding author: Dr P-C. Shaw.

\section{Screening for restriction endonucleases}

The isolates were grown at $37^{\circ} \mathrm{C}$ overnight in $5 \mathrm{ml}$ of $\mathrm{L}$ broth: bacterial tryptone (Difco) $1 \%$, bacterial yeast extract (Difco) $0.5 \%, \mathrm{NaCl} 1 \% \mathrm{w} / \mathrm{v}$. The cells from $1.5 \mathrm{ml}$ of the broth culture were collected by centrifugation and resuspended in $0.4 \mathrm{ml}$ of column buffer (10 mM Tris- $\mathrm{HCl}, \mathrm{pH} 7.5,5 \mathrm{mM} \beta$-mercaptoethanol, $1 \mathrm{mM}$ EDTA, glycerol 5\%, $1 \mathrm{mM}$ phenylmethylsulphonyl fluoride). After disruption of the cells by sonication in an ice-water bath and centrifugation to remove the cell debris, $1 \mu \mathrm{l}$ of the supernate was incubated with $14 \mu \mathrm{l}$ of a reaction mixture containing $50 \mathrm{mM} \mathrm{NaCl}$, $50 \mathrm{mM}$ Tris- $\mathrm{HCl}, \mathrm{pH} 7.5,10 \mathrm{mM} \mathrm{MgCl}_{2}, 1 \mathrm{mM}$ dithiothreitol and a mixture of phage $\mathrm{T} 7$, adenovirus- 2 and phage lambda DNA at $37^{\circ} \mathrm{C}$ for $15 \mathrm{~min}$. The digested product was analysed by electrophoresis on an agarose $0.8 \%$ gel in Tris-borate-EDTA (TBE) buffer [9].

Isolates in which sonicates exhibited restriction endonuclease activity were grown overnight in $300 \mathrm{ml}$ of $\mathrm{L}$ broth at $37^{\circ} \mathrm{C}$ with shaking. The cultures were centrifuged at $3840 \mathrm{~g}$ for $15 \mathrm{~min}$. The cell pellet was resuspended in $15 \mathrm{ml}$ of column buffer and the cells were lysed as described previously [10]. The lysate was loaded on to a heparin-agarose column $(18 \times 10 \mathrm{~cm})$. Restriction endonuclease was eluted with a $0-1 \mathrm{M} \mathrm{NaCl}$ gradient in $300 \mathrm{ml}$ of column buffer and 1-ml fractions were collected.

\section{Antimicrobial susceptibility tests and serotype determination}

The antibiotic susceptibility of the Shigella isolates was determined by the agar dilution method as described 
previously [7]. The isolates were serotyped by slide agglutination with specific antisera (Wellcome Research Laboratories, Beckenham).

\section{Southern hybridisation}

Plasmid DNA was extracted from the isolates according to the method of Kado and Liu [11], electrophoresed on an agarose $0.7 \%$ gel in TBE buffer [9] and stained with ethidium bromide for UV visualisation. Plasmids separated on gels were then transferred on to Hybond$\mathrm{N}+$ nylon membranes (Amersham) by a vacuum blotting system (Vacugene, LKB, Bromma, Sweden). Membranes were hybridised with a $400-$ bp Bam HI$E c o$ RV fragment within the EcoRII restriction endonuclease-encoding gene. Pre-hybridisation was at $65^{\circ} \mathrm{C}$ for $1 \mathrm{~h}$ in $6 \times \mathrm{SSC}(1 \times \mathrm{SSC}$ is $0.15 \mathrm{M} \mathrm{NaCl}, 0.015 \mathrm{M}$ sodium citrate, $\mathrm{pH} 7.0), 5 \times$ Denhardt's solution [12], denatured salmon sperm DNA $100 \mathrm{mg} / \mathrm{L}$ and SDS $0.5 \%$. Hybridisation was performed at $65^{\circ} \mathrm{C}$ for $12 \mathrm{~h}$ in a solution containing $6 \times \mathrm{SSC}, 5 \times$ Denhardt's solution, denatured salmon sperm DNA $100 \mathrm{mg} / \mathrm{L}$ and labelled probe at a concentration of $1 \mathrm{ng} / \mathrm{ml}$. The probe was labelled with $\left[\alpha-{ }^{32} \mathrm{P}\right] \mathrm{dCTP}$ (Amersham) with the Megaprime $^{\mathrm{TM}}$ DNA labelling kit (Amersham) according to the manufacturer's instructions. Unincorporated radioactive nucleotides were removed by passing through prepacked Bio-Spin ${ }^{\circledR}$ chromatography columns (BioRad Laboratories, CA, USA). Membranes were washed with $2 \times \mathrm{SSC}$, SDS $0.1 \%$ for 5 and $10 \mathrm{~min}$ at room temperature with $0.5 \times \mathrm{SSC}$, SDS $0.1 \%$ for $15 \mathrm{~min}$ at $65^{\circ} \mathrm{C}$ and finally with $0.1 \times \mathrm{SSC}$, SDS $0.1 \%$ twice for $15 \mathrm{~min}$ at $65^{\circ} \mathrm{C}$. Hybridised membranes were exposed to X-ray films (Kodak, Rochester, NY, USA) at $-70^{\circ} \mathrm{C}$ for $1-3$ days.

\section{Results}

Among the 186 isolates examined, 13 were found to contain restriction endonucleases. Table 1 summarises their characteristics. The partially purified enzymes were used to digest DNA preparations of known sequence. The enzymes were shown to be either $N c i$ I (Fig. 1a) or EcoRII (Fig. 1b) isoschizomers which recognise CCSGG or CCWGG, respectively. The isolates containing $\mathrm{NciI}$ isoschizomers were resistant to only one or two antibiotics and all harboured a 5.7kb plasmid (Fig. 2a and Table 1). This plasmid was not transferable to an Escherichia coli strain by either conjugation or transformation.

In contrast, the isolates containing EcoRII isoschizomers harboured multiple plasmids with similar, although non-identical, profiles (Fig. 2a). Hybridisation of the plasmid DNA with a probe containing part of the EcoRII gene showed that there was high homology between the EcoRII gene and a 46.6- or 55.6-kb plasmid (Fig. 2b). These plasmids were transferable to $E$. coli by conjugation.

The plasmid profiles of 113 isolates that did not contain restriction endonucleases were determined. Ten isolates with multiple plasmids also contained a $5.7-\mathrm{kb}$ plasmid and of these, one was resistant to streptomycin only and one to streptomycin and tetracycline. On the other hand, three isolates resistant to multiple antibiotics contained a $46.6-\mathrm{kb}$ or a $55.6-\mathrm{kb}$ plasmid, together with other plasmids of different sizes.

\section{Discussion}

Restriction endonucleases have been found in many different bacteria. Usually, isoschizomers from different species have unrelated sequences [13]. Nevertheless, there are only a few reports on the use of restriction enzymes in epidemiological studies. Miyahara et al. found isoschizomers of restriction endonuclease Pst I to occur at a high frequency in Yersinia enterocolitica serotype 08 strains [14]. Subsequently, this group has also correlated the occurrence of three

Table 1. Characteristics of Shigella isolates with restriction endonuclease activity

\begin{tabular}{rllll}
\hline $\begin{array}{l}\text { Shigella } \\
\text { strain }\end{array}$ & Serotype & $\begin{array}{l}\text { Antibiotic } \\
\text { resistance }\end{array}$ & $\begin{array}{l}\text { Restriction } \\
\text { endonuclease }\end{array}$ & Isoschizomer of \\
\hline 11573 & F2 & ST & SflHK11573I & NciI \\
11087 & F2 & S & SflHK11087I & NciI \\
11086 & F2 & S & SflHK11086I & NciI \\
7462 & So & ASTCKSuTmSxtG & Sso HK7462I & EcoRII \\
11572 & F3 & S & SflHK11572I & NciI \\
10695 & So & ST & Sso HK10695I & NciI \\
7234 & So & ASTCSuTmSxtG & Sso HK7234I & EcoRII \\
6873 & So & ASTCKSuTmSxtG & Sso HK6873I & EcoRII \\
2374 & F1 & ASTCSu & SflHK2374I & EcoRII \\
2731 & F1 & ASTCSuTmSxtGCthMaCp & SflHK2731I & EcoRII \\
1794 & So & ASTCSuTmSxtG & SsoHK1794I & EcoRII \\
8401 & F1 & ASTCKSuTmSxt & SflHK8401I & EcoRII \\
10790 & So & ASTCKSuTmSxtG & SsoHK10790I & EcoRII \\
\hline
\end{tabular}

F1, flexneri serotype 1; F2, flexneri serotype 2; F3, flexneri serotype 3; So, sonnei; A, ampicillin; $\mathrm{S}$, streptomycin; T, tetracycline; $\mathrm{C}$, chloramphenicol; $\mathrm{K}$, kanamycin; Su, sulphamethoxazole; Tm, trimethoprim; Sxt, cotrimoxazole; G, gentamicin; $\mathrm{Cth}$, cephalothin; $\mathrm{Ma}$, cephamandole; $\mathrm{Cp}$, cefoperazone. 
a

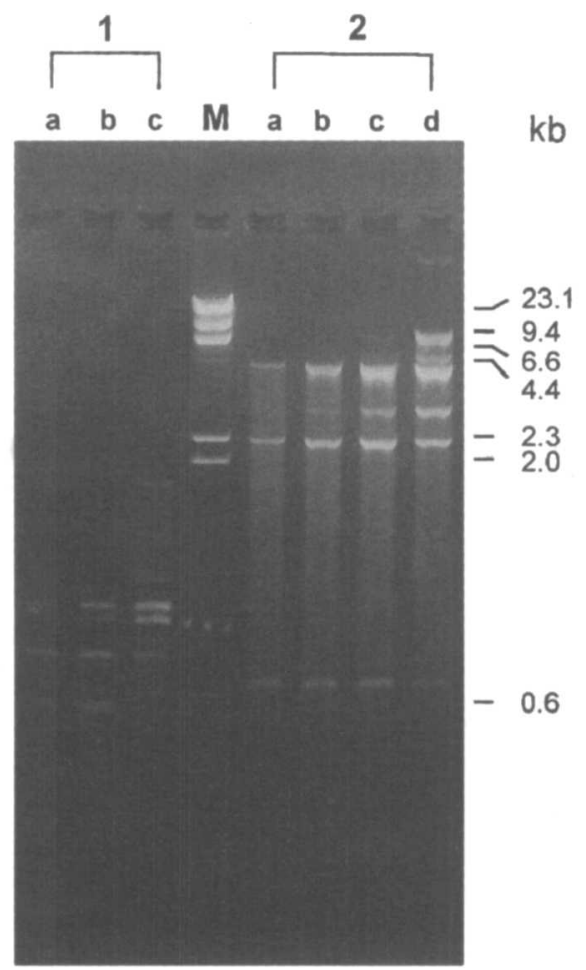

b
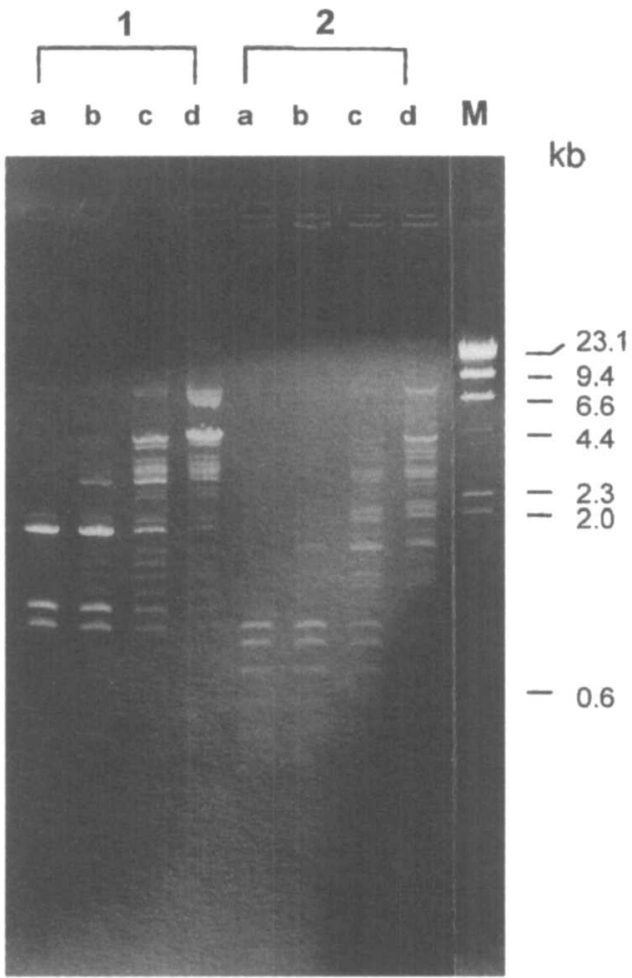

Fig. 1. (a) Digestion of (1) non-methylated pUC19 and (2) M13mp18DNA by (a) 4, (b) 2, (c) 1 and (d) $0.5 \mu 1$ of Shigella 10695 enzyme. (b) Digestion of (1) non-methylated pBR322 and (2) non-methylated pACYC184 DNA by (a) 4, (b) 2, (c) 1 and (d) $0.5 \mu 1$ of Shigella 10790 enzyme. M: $\lambda$ hindIII marker.

b

$$
\begin{array}{llllllllllllllll}
12 & 3 & 4 & 5 & 6 & 7 & 8 & 9 & 10 & 11 & 12 & 14 & 15 & 16 & 17
\end{array}
$$

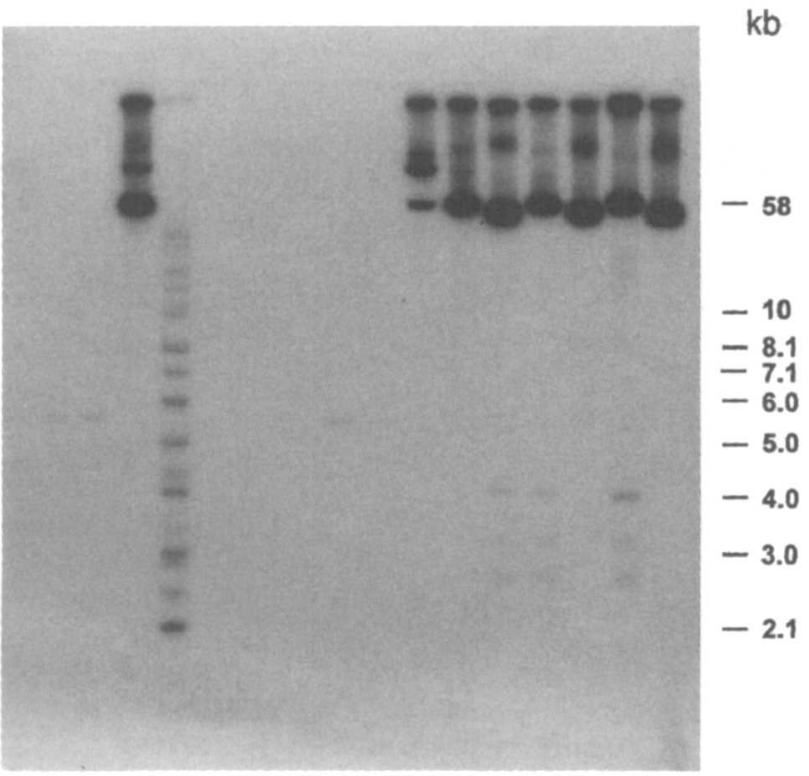

Fig. 2. (a) Profile and (b) Southern hybridisation of plasmid DNA from Shigella isolates containing EcoRII or NciI isoschizomers. Lanes 1-4, Shigella isolates $11573,11087,11086$ and $7462 ; 5$, supercoiled DNA ladder (BRL cat no. S622SA); 6, marker 28R823 of $221 \mathrm{~kb}$; 7, markers 40R448, RT641, 48R626 of 119, 91 and $62 \mathrm{~kb}$, respectively; 8, markers 40R268, 40R646 of 98 and $58 \mathrm{~kb}$, respectively; 9-17 Shigella isolates 11572, 10695, 7234, 6873, 2374, 2731, 1794,8401 and 10790 .

restriction endonucleases to three serotypes of Salmonella [15].

In the present study, 13 of the 186 Shigella isolates were found to contain $\mathrm{Nci}$ I or EcoRII isoschizomers.
There appeared to be no relationship between serotype and the occurrence of these enzymes in Shigella, indicating that the two characteristics had not coevolved. On the other hand, there was a correlation between the two restriction endonucleases, plasmid 
profile and antibiotic resistance. The $\mathrm{Nci}$ I isoschizomer was found only in isolates resistant to one or two antibiotics and having a single $5.7-\mathrm{kb}$ plasmid. The plasmid profiles of isolates containing the EcoRII isoschizomers were similar; the strains were resistant to multiple antibiotics (Table 1) and only a very few strains containing a 46.6 - or $55.6-\mathrm{kb}$ plasmid had escaped the detection of EcoRII isoschizomer. Therefore, these two R-M systems may be used in addition to plasmid profile and antibiotic resistance for tracing Shigella strains. As the DNA encoding EcoRII isoschizomers in Shigella were able to hybridise to an EcoRII gene probe, and the latter gene is carried on a large $\mathrm{R}$ plasmid with conjugal transfer ability $[3$, $16]$, it is likely that both the EcoRII R-M system and its Shigella counterpart have the same origin. The identity of the Shigella plasmid which carries the EcoRII isoschizomer gene is being sought, in order to reveal if the $\mathrm{R}$ plasmid in $E$. coli has spread to these Shigella strains.

K.F.L. was supported by a post-doctoral fellowship from the Chinese University.

\section{References}

1. Roberts RJ, Macelis D. REBASE - restriction enzymes and methylases. Nucleic Acids Res 1996; 24: 223-235.

2. Roberts RJ, Halford SE. Type II restriction endonucleases. In: Linn SM, Lloyd RS, Roberts RJ (eds) Nucleases, 2nd edn. Cold Spring Harbor, NY, Cold Spring Harbor Press. 1993: 35-88.

3. Yoshida Y, Mise K. Occurrence of small Hsd plasmids in Salmonella typhi, Shigella boydii, and Escherichia coli. J Bacteriol 1986; 165: 357-362.

4. Mise K, Nakajima K, Terakado N, Ishidate M. Production of restriction endonucleases using multicopy Hsd plasmids occurring naturally in pathogenic Escherichia coli and Shigella boydii. Gene 1986; 44: 165-169.

5. Naito T, Kusano K, Kobayashi I. Selfish behavior of restriction-modification systems. Science 1995; 267: 897-899.

6. Hong Kong Government, Department of Health. Notification of Infectious Diseases, 1990-92.

7. Ling J, Kam KM, Lam AW, French GL. Susceptibilities of Hong Kong isolates of multiply resistant Shigella spp. to 25 antimicrobial agents, including ampicillin plus sulbactam and new 4-quinolones. Antimicrob Agents Chemother 1988; 32: 20-23.

8. Ling JM, Shaw PC, Kam KM, Cheng AF, French GL. Molecular studies of plasmids of multiply-resistant Shigella spp. in Hong Kong. Epidemiol Infect 1993; 110: 437-446.

9. Meyers JA, Sanchez D, Elwell LP, Falkow S. Simple agarose gel electrophoretic method for the identification and characterization of plasmid deoxyribonucleic acid. J Bacteriol 1976; 127: $1529-1537$.

10. Leung SM, Kam KM, Chan KY, Shaw PC. Purification and characterization of restriction endonuclease $B c o$ I from a soil isolate of Bacillus coagulans. FEMS Microbiol Lett 1990; 66: 153-156.

11. Kado, CI, Liu S-T. Rapid procedure for detection and isolation of large and small plasmids. $J$ Bacteriol 1981; 145: 1365-1373.

12. Sambrook J, Fritsch EF, Maniatis T. Molecular cloning: a laboratory manual 2nd edn. Cold Spring Harbor, NY, Cold Spring Harbor Laboratory Press. 1989.

13. Wilson GG. Organization of restriction-modification systems. Nucleic Acids Res 1991; 19: 2539-2566.

14. Miyahara M, Maruyama T, Wake A, Mise K. Widespread occurrence of the restriction endonuclease Yen I, an isoschizomer of Pst I, in Yersinia entercolitica serotype 08. Appl Environ Microbiol 1988; 54: 577-580.

15. Miyahara M, Kudoh Y, Mise K. Widespread occurrence of specific restriction endonucleases in Salmonella infantis, Salmonella thompson, and Salmonella blockley isolated from humans in Japan. Appl Environ Microbiol 1990; 56: 22482250.

16. Rouland-Doussoix D, Yoshimori $R$, Greene $P$, Betlach $M$, Goodman HM, Boyer HW. R factor-controlled restriction and modification of deoxyribonucleic acid. In: Schlessinger D (ed) Microbiology. Washington, DC, American Society for Microbiology. 1975: 187-198. 